\title{
MORPHOLOGICAL EVOLUTION OF THE BOTTOM OF THE POTOU LAGOON OVER THE LAST TEN YEARS (COASTAL ZONE OF COTE D'IVOIRE)
}

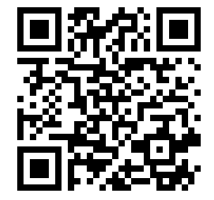

\author{
Diangone Eric ${ }^{* 1} 凹$, Akobe Apie Colette ${ }^{2}$, Amani Etché Mireille 2 , Monde Sylvain ${ }^{2}$, \\ Coulibaly Aoua ${ }^{2}$ \\ ${ }^{* 1,2}$ Laboratoire de Géologie Marine et Sédimentologie, Université de Cocody, 22 B.P. 801 Abidjan \\ 22, Côte d'Ivoire
}

DOI: https://doi.org/10.29121/granthaalayah.v8.i10.2020.1588

Article Type: Research Article

Article Citation: Diangone Eric, Akobe Apie Colette, Amani Etché Mireille, Monde Sylvain, and Coulibaly Aoua. (2020).

MORPHOLOGICAL EVOLUTION OF THE BOTTOM OF THE POTOU LAGOON OVER THE LAST TEN YEARS (COASTAL ZONE OF COTE D'IVOIRE). International Journal of Research -GRANTHAALAYAH, 8(10), 37-46.

https://doi.org/10.29121/granthaa layah.v8.i10.2020.1588

Received Date: 15 September 2020

Accepted Date: 23 October 2020

Keywords:

Bathymetry

Morphology

Sedimentation

Potou Lagoon and Ivory Coast

\section{ABSTRACT}

This study with a morphology and hydrosedimentology character was done to carry out a with an understanding the evolution of the channels and sedimentation in Potou lagoon in Ivory Coast starting from the realization of the bathymetric map. The bathymetry of this lagoon avered that the depths are lower than $2.11 \mathrm{~m}$ out of $22 \mathrm{~km} 2$, and presente three types of channels. In fact the channels in "U" represent a balance between the agents of accumulation and erosion. Channels resulting from processes of erosion which are in "V" and channels intermediate indicating an evolution of the type "V" in "U". In particular during these fourteen last years the Potou lagoon has sudden great phenomenon of deposit is a volume of $+66791000.18 \mathrm{~m}^{3}$ of sediments deposed on a surface which is thus estimated at $65.2 \%$ of chenal surface. These deposits are certainly causes of full high funds in this lagoon. The mean velocity of sedimentation on Potou lagoon is thus estimated at $26.5 \mathrm{~cm} /$ year. As for the erosion, it could be estimated at-8487601 $\mathrm{m}^{3}$ a volume of on a surface wich is thus estimated at $34 \%$ of chenal surface. The sedimentary budget would be thus estimated at $+58303398.68449 \mathrm{~m}^{3}$ on a surface of $12.45 \mathrm{~m} 2$. A surface which is thus estimated at $0.8 \%$ hasn't sudden phenomenon of deposit or erosion. The bathymetric chart and the sedimentary budget of Potou lagoon are tools necessary for use of the stretch of water by the users. Thus, the zones at the risks determined on the bathymetric chart, such as the high bottom and the points of swirl generated by the depressions, will be easily avoided.

\section{INTRODUCTION}

In Côte d'Ivoire, the lagoons are mainly gathered along the eastern half of the coastline to Ghana for nearly 300 $\mathrm{km}$. This complex covers an area of approximately $1200 \mathrm{~km} 2$ and consists of three separate lagoons. These are from West to East, the lagoons of Grand-Lahou, Ebrie and Aby. Initially separated, they were connected thanks to the piercing of canals (canal of Asagny in 1939 and channel of Assinie in 1957) which allow the circulation of small boats on nearly $300 \mathrm{~km}$ of coast, until the border of Ghana.

The Ebrie system occupies a depression partly guided by the half-rift structure of the stable African margin. In the region of Abidjan, these depressions correspond to ancient valleys. They are carved in the Cenozoic and

(C) 2020 The Author(s). This is an open access article distributed under the terms of the Creative Commons Attribution License, which permits unrestricted use, distribution, and reproduction in any medium, provided the original author and source are credited. 
Quaternary formations of the sedimentary basin and isolated from the sea by sandy, marine, Holocene strands. The country is drained by a well-structured hydrographic network crossing the country into the sea. Only the artificial channel of Vridi, at the entrance of the lagoon port of Abidjan, connects the lagoon to the sea permanently (figure 1).

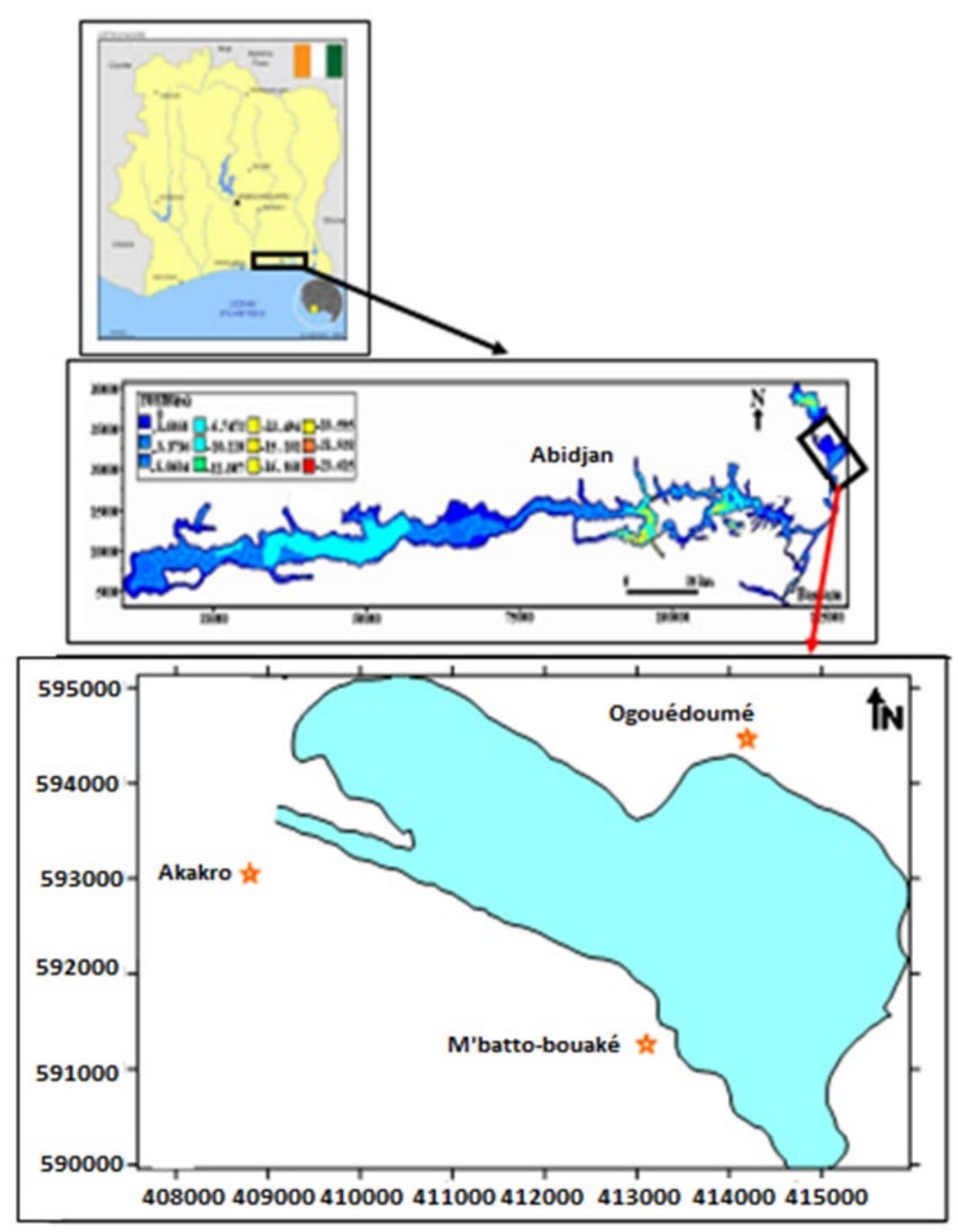

Figure 1: Location of the study area

The lagoon system consists of the Ebrie Lagoon proper, which has a surface area of $523 \mathrm{~km} 2$ and Potou and Adjin lagoons, which share $43 \mathrm{~km} 2$. The Ebrie lagoon consists of a central basin, a western arm and an eastern arm. The region of Abidjan occupies the central basin of the Ebrie lagoon which communicates with the Atlantic Ocean by the artificial channel of Vridi and the bay of Abidjan.

The morphology of these lagoons has been the subject of several works, but particularly the lagoon system Ebrie for its economic advantages. Preserving this environment and their living resources is a sustainable management issue. It is therefore of utmost importance, both ecologically, economically and socially, to understand the functioning of this environment in order to better manage it.

The Ebrié lagoon system is supplied with fresh water by the Agnéby, Mé and Comoé rivers (Figure 2). Its geometric complexity leads to the individualization of particular hydrological environments.

The Potou Lagoon with an area of $22.8 \mathrm{~km} 2$, which is the subject of our study, is an inland lagoon. It is part of the lagoon system Ebrié, the largest lagoon system in Côte d'Ivoire, with an area of $566 \mathrm{~km} 2$. The Potou Lagoon is located between the Adjin Lagoon and the Ebrié Lagoon proper. It is surrounded by three villages: Oguedoumé, M'batto-bouaké and Akakro. 
The Potou Lagoon, a subset of the Ebrié system is a freshwater environment that is subject to the modest contributions of small rivers (Djibi, Bété) and those of the Mé that opens between the two lagoons. (Tastet and Guiral, 1994).

\section{ACQUISITION, DATA PROCESSING EQUIPMENT AND METHODS OF STUDY}

\subsection{STUDY MATERIAL}

\subsubsection{FIELD EQUIPMENT}

The equipment used during the mission for the bathymetric survey consists of a motorboat (Figure A) which has:

- a power supply through which the echosounder is energized during the acquisition session "YT4 beater" (Figure C);

- a "LOWRANCE" echo sounder (Figure B + D) that includes the following components:

- a central unit that receives and converts analog signals into digital data (Figure B);

- a GPS (Global Positioning System) incorporated into the central unit which continuously gives the geographical coordinates of the probe point;

- a transducer that allows the transmission of the signal by converting electrical energy into acoustic energy (Figure D).

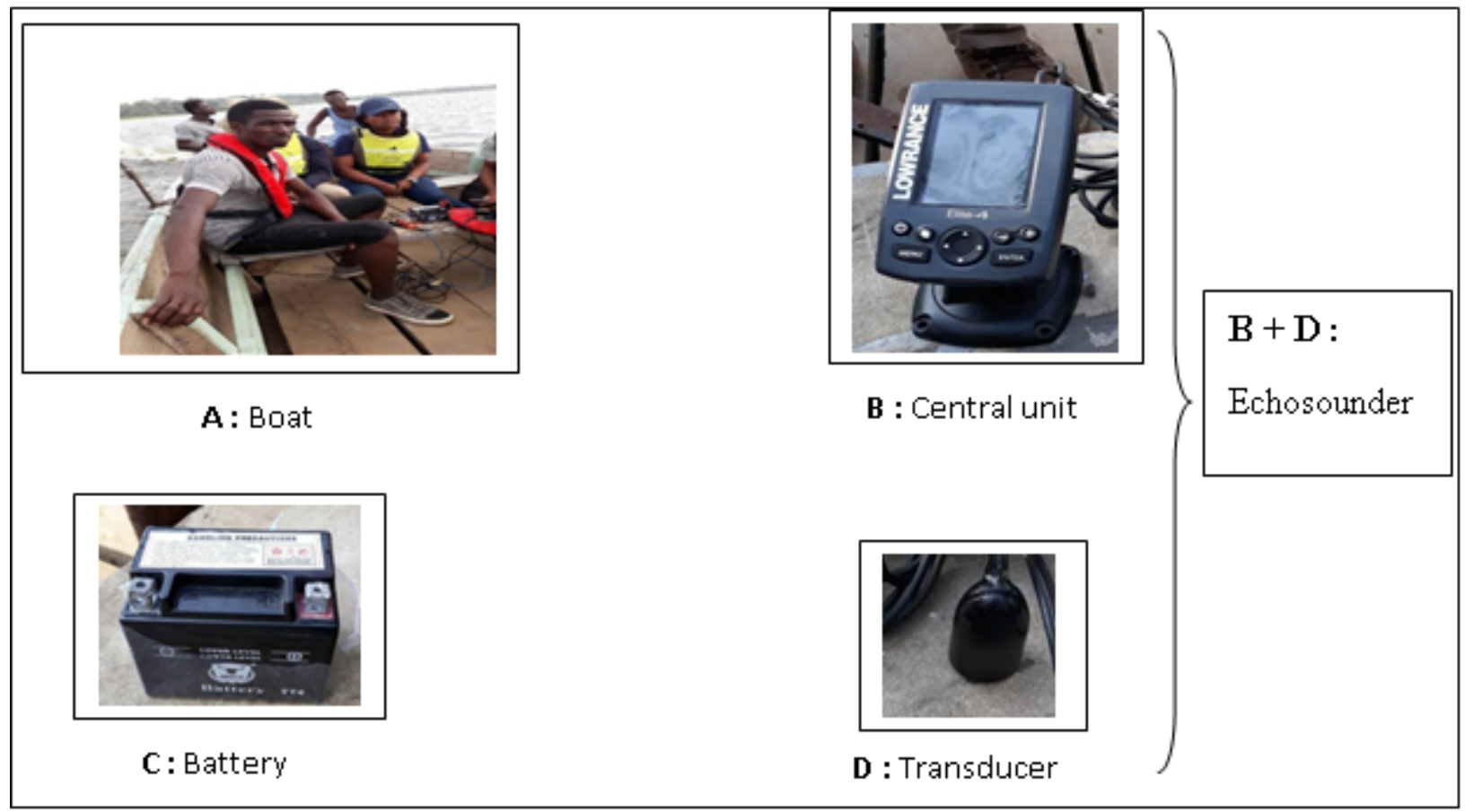

Plate 1: Equipment used for the bathymetric survey

\subsubsection{DATA PROCESSING EQUIPMENT}

All the data collected in the field will be processed by means of a computer integrated with the following programs: google earth to obtain the coordinates of the contour and Surfer 13 for the realization of the bathymetric map. The latter offers two windows:

the "Worksheet" and the "Plot doc". The Worksheet is used to record data and the

"Plot doc" is used for making maps. 


\subsection{STUDY METHODS}

\subsubsection{METHODS OF DATA ACQUISITION}

\section{Positioning System}

GPS is a universal satellite positioning system. It continuously provides the $\mathrm{X}$ and $\mathrm{Y}$ coordinates of positioning and navigation data (Reiner et al., 1992). The GPS manages to capture at least four (4) satellites in any point of the earth. This allows him to give the exact coordinates of the positioning points. For this study a GPS receiver coupled to the echo sounder was used. It has an accuracy of about $2 \mathrm{~m}$ in ideal conditions (clear sky).

\section{Bathymetric Surveys}

Bathymetric surveys were carried out in February 2018 on the Potou lagoon in order to know the morphology of the bottom. These surveys consist of measuring the depth. The following measurements were made of radials approximately perpendicular to the shores of the Potou lagoon so as to cover almost the entire surface of the lagoon (Figure 2).

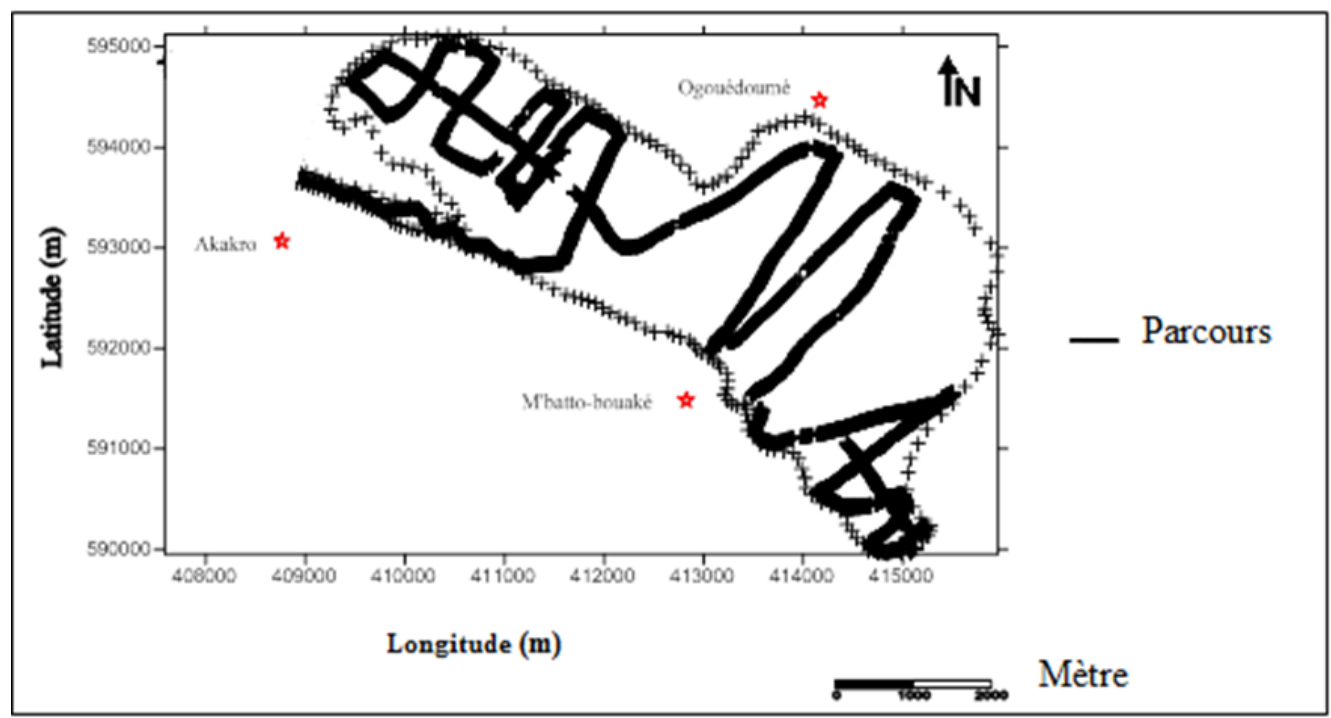

Figure 2: Positioning map of the probe points in the Potou Lagoon (2018)

\section{Operating Principle of Single Beam Sounder}

The transducer connected to the central unit and mounted on a support is attached to the hull of the outboard to a depth of $30 \mathrm{~cm}$ to avoid contact with the floating elements (floating plants, pieces of wood in suspension, etc ...) in area. Thus, the acoustic beam is oriented downwards and explores the bottom. The GPS receiver is incorporated in the central unit. The central unit is powered by a "YT4" battery.

Once in the water, during the operation an electric pulse produced by the transmitter (central unit) is amplified and converted into an acoustic pulse by the transducer. The latter, in transmission mode, propagates in the aquatic environment the acoustic signal during the period corresponding to the duration of the pulse. Any target in the acoustic signal path will echo the transducer. The latter, in reception mode, transforms the acoustic pulse (mechanical) into an electrical pulse, then transmits it to the central unit (Monde, 1997). The signal reaches the receiver where it is processed and amplified again (due to propagation losses). A time base converts the reception offset of the echo into a distance (numerical data).

\subsubsection{PROCESSING ECHO SOUNDING DATA}

\section{Probe Correction}

After recording on the memory card and retrieving the data on a computer for processing, corrections are made and the actual depth at each point is determined. These corrections concern the immersion depth of the transducer which was $30 \mathrm{~cm}$. At each point, the actual depth is obtained after adding the depth of immersion of the transducer 
$(+30 \mathrm{~cm})$ to the depth read on the echo sounder. After correction, the probe data is processed and analyzed using the Surfer 13 software.

\section{Development of Bathymetric Charts}

From a satellite image obtained using Google Earth, the contours of the Potou lagoon have been determined. The Bathymetric Maps of the Potou Lagoon were developed using 9115 probe points and using the "SURFER" mapping software stored in an Excel X, Y and Z spreadsheet.

\section{RECENT MORPHOLOGY OF THE POTOU LAGOON}

\subsection{BATHYMETRIC CHART OF THE POTOU LAGOON (2018)}

The examination of the bathymetric map (Figure 3), presents isobaths ranging from 0 to $13 \mathrm{~m}$ on the $22.8 \mathrm{~km} 2$ of the Potou lagoon. The $0 \mathrm{~m}$ isobath delimits the Potou lagoon and the average depth is $2.11 \mathrm{~m}$. Depths greater than $2 \mathrm{~m}$ are located in the natural channel connecting the Potou Lagoon and the Adjin Lagoon where they reach $6 \mathrm{~m}$, at the entrance to the west where they reach $13 \mathrm{~m}$ and at its exit to the east where they reach $6 \mathrm{~m}$.

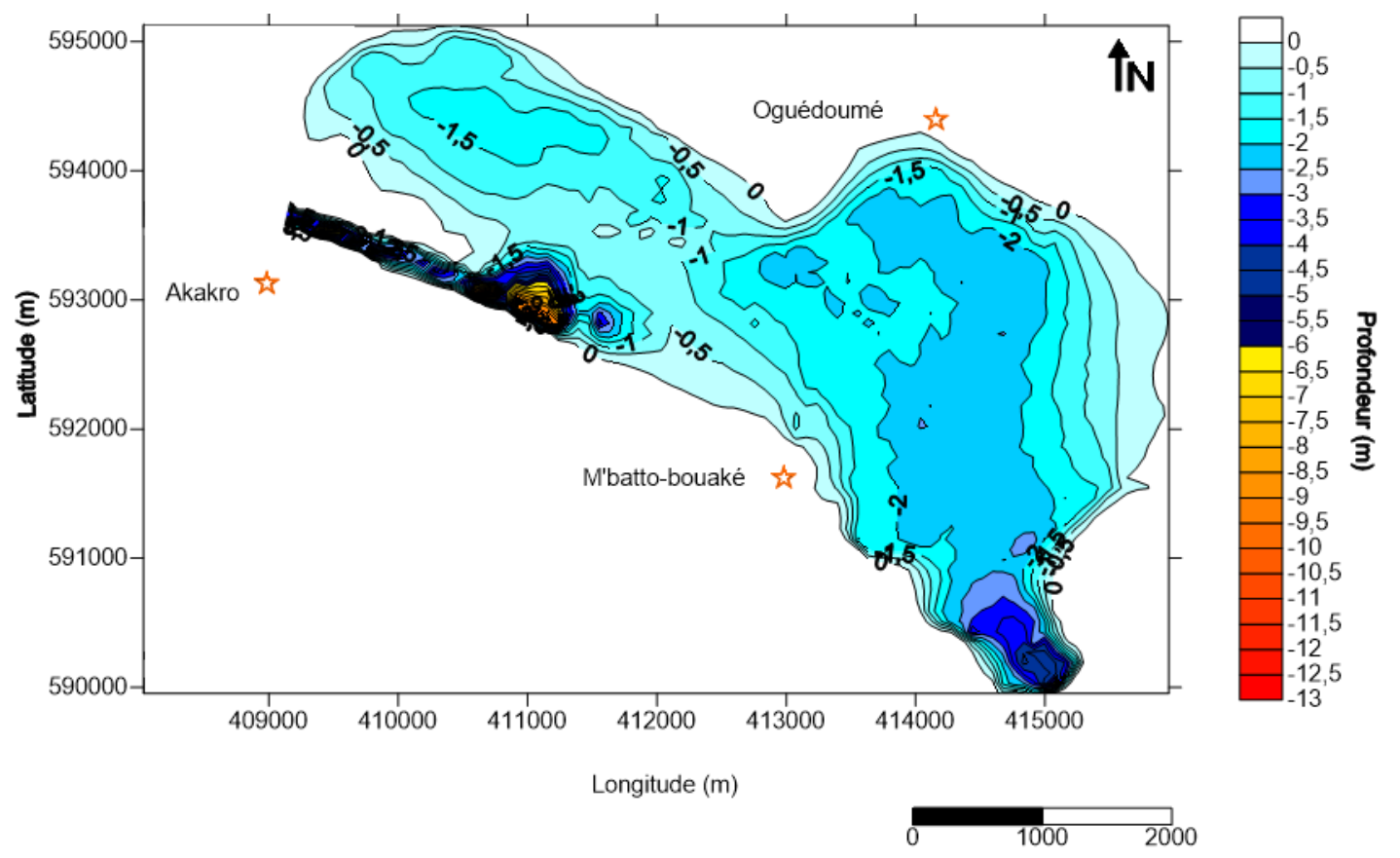

Figure 3: Bathymetric map of the Potou Lagoon (2018)

\subsection{DIGITAL TERRAIN MODEL (DTM) OF THE POTOU LAGOON (2018)}

The digital terrain model (DTM) or the 3D map of the Potou lagoon (Figure 4) shows its morphological aspects. These are shoals and depressions. It clearly shows the preponderance of shoals on the entire lagoon. The depressions are located in the canal that connects it to the Adjin lagoon and its western entrance, the entrance to the canal linking it to the Ebrié lagoon proper. These shallow shoals represent difficult areas for navigation while depressions, deeper, therefore conducive to navigation. These shoals reflect fairly calm hydrodynamic conditions. Their formation is due to an accumulation of sediments, which would come from the Mé and from the runoff of the banks. On the other hand, the depressions are caused by the accentuation of the erosion which would be due to the speed of the current of water coming from Mé which has for its exit the channel connecting the lagoons Adjin and Potou. 


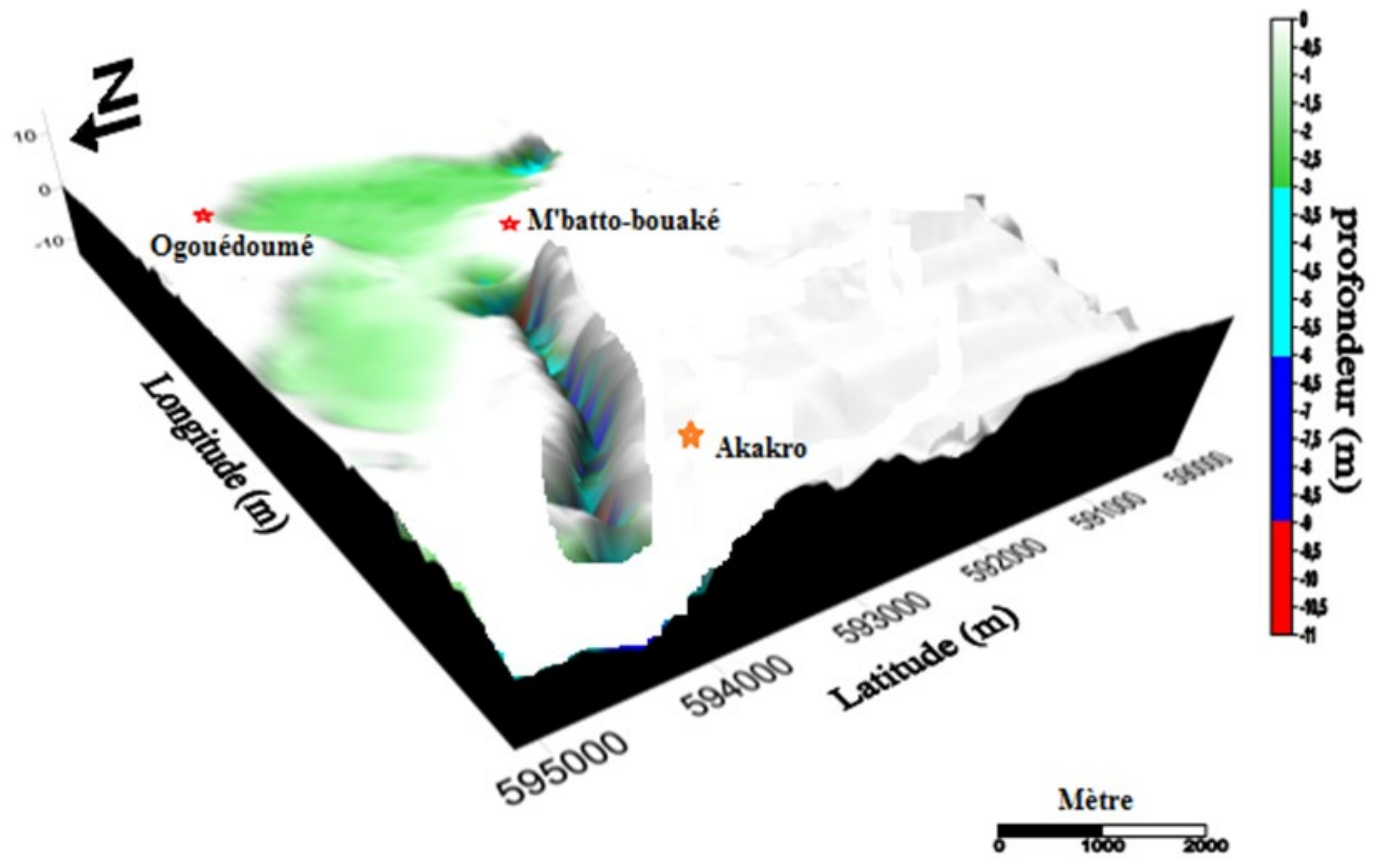

Figure 4: Digital Terrain Model (DTM) of the Potou Lagoon (2018)

\subsection{SLOPES OF THE POTOU LAGOON}

The software Surfer, by generating the map of the slopes establishes a differentiation between them. In general, the slopes are located around the lagoon. Figure 5 allows to have values in degrees of slopes to better appreciate them. Table I makes it possible to locate the slopes and to appreciate their typologies. The analysis of Figure 5 and Table VII reveals that the slopes are generally weak. This shows the existence of a little rugged terrain. The horizontal slopes between $0^{\circ}$ and $0.3^{\circ}$ lined the interior of the Potou lagoon thus showing the preponderance of horizontal relief over the entire lagoon. The subhorizontal slopes between $0.3^{\circ}$ and $1.2^{\circ}$ are located around the lagoon. We note the presence of very low slopes between $0.3^{\circ}$ and $3^{\circ}$ at its east exit and in the canal connecting the two lagoons Adjin and Potou. The strongest slope is of moderate type $\left(6^{\circ}\right)$ and is located at the western entrance of the Potou lagoon.

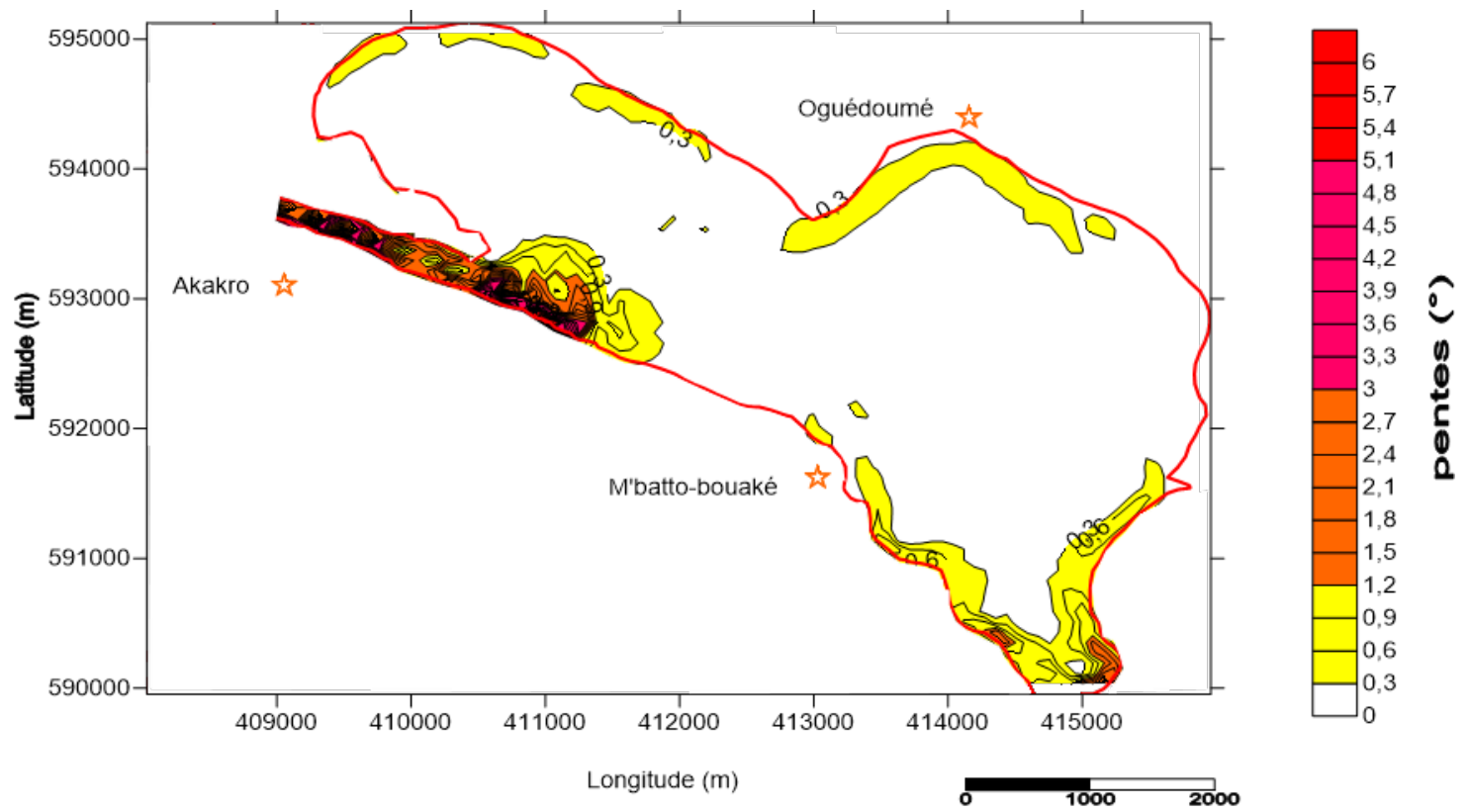

Figure 5: Map of the slopes of the Potou Lagoon (2018) 
Diangone Eric, Akobe Apie Colette, Amani Etché Mireille, Monde Sylvain, and Coulibaly Aoua

Table I: Classification of the slopes of the Potou Lagoon (2018)

\begin{tabular}{|c|c|c|}
\hline Zones & Incline $\left(^{\circ}\right)$ & Typologies \\
\hline Channel & $0,3-3$ & Very low \\
\hline Surroundings & $0,3-1,2$ & Subhorizontal \\
\hline West entrance & $0,3-6$ & Moderate \\
\hline Interior & $0-0,3$ & Horizontal \\
\hline East exit & $0,3-3$ & Very low \\
\hline
\end{tabular}

Zones Slopes $\left({ }^{\circ}\right)$ Typologies

Channel 0.3 - 3 Very low

Surroundings 0.3 - 1.2 Subhorizontal

West Entrance 0.3 - 6 Moderate

Inner 0 - 0.3 Horizontal

Output East 0.3 - 3 Very low

\subsection{CHARACTERIZATION OF THE CHANNELS}

The characterization of the channels of the Potou lagoon has been studied from 7 radials (Figure 6). They can be grouped into two preferential directions:

- Direction S - N: this is the orientation of the radial R 1, R 2, R 3, R 4, R 5 and R 6 according to the respective longitudes 409000, 410000, 411000, 412000, 413000, 414000, 414000 and 415000 Where is.

- $\quad$ SE - NW direction: This is the longitudinal radial R 7.

They make it possible to draw profiles of the lagoon starting from a bank South to the other bank North and longitudinally of the bank East to the bank West. Thus, the dominant phenomenon in these different places namely erosion or fattening could be highlighted

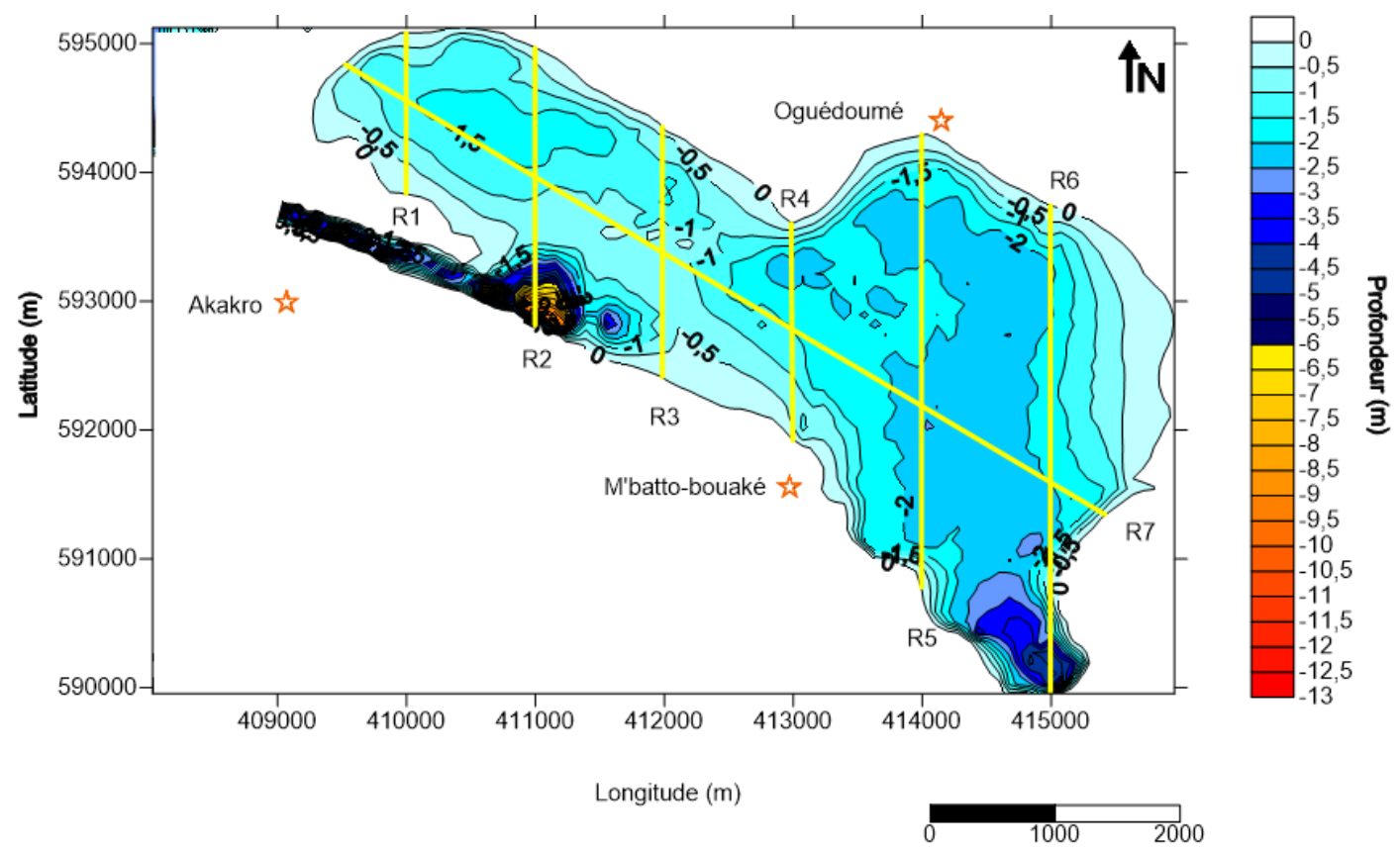

Figure 6: Positioning Map of the Radials of the Potou Lagoon

\subsubsection{INTERPRETATION OF PROFILES}

Following analysis of the different profiles from the 7 radials, there are three morphological types of channels: the "U" type, the "V" type and the intermediate type (between $U$ and V). 


\section{Intermediate Profiles}

Figure 7 allows to locate and show intermediate bathymetric profiles:

- With a maximum depth of up to $11 \mathrm{~m}$, profile 2 has a regular and asymmetrical morphology.

- Profile 3, with a maximum depth of less than $2 \mathrm{~m}$, has an irregular and asymmetrical morphology.

- The profile 6 with a maximum depth of less than $5 \mathrm{~m}$, has an irregular and asymmetrical morphology.

- Profile 7 has a maximum depth of approximately $2.5 \mathrm{~m}$ with an irregular and asymmetrical morphology.

These channels are between the "V" and "U" morphology channels. These channel types have not yet reached their equilibrium form or reached it and subsequently undergo a new phase of erosion. The action of accumulation agents and erosion agents do not balance. These agents make it possible to follow and understand the evolution process of an erosion profile that is characterized by the transition from the "V" profile to the "U" profile (Adopo, 2009 and Amani, 2012) and also the transition from a U-channel in a V channel.

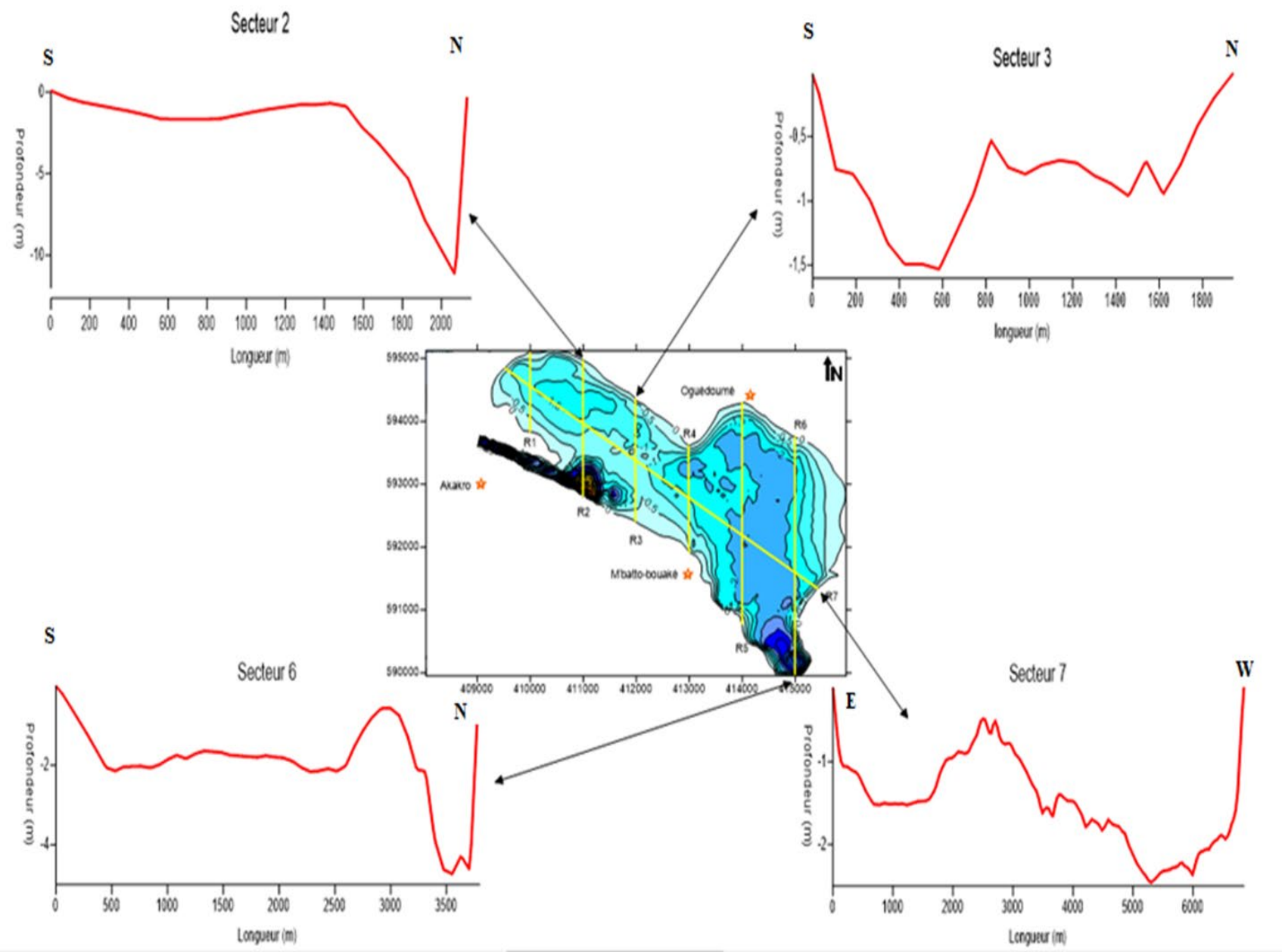

Figure 7: Intermediate Bathymetric Profiles of the Potou Lagoon (2018)

\section{"U" profile}

Profile 5 (Figure 8) has an irregular and symmetrical morphology of "U" shape with a maximum depth of less than $3 \mathrm{~m}$. It is concave, flared and flattened at the base. Channels with a "V" profile are gradually transformed under the effect of transport - deposit phenomenon to adopt a "U" profile. The "U" profile is an equilibrium profile of action between storage agents and erosion agents. But a new action of erosion can resume and recommit the work of digging. We are talking here about cyclical action. 


\section{"V" profiles}

Profiles 1 and 4 with maximum depths of 2 m highlight "V" channels (Figure 9).

Profile 1 has a regular and symmetrical morphology while Profile 4 has an irregular and asymmetrical morphology that is translated as a predominance of erosion agents on the builders.

The channel with a "V" type profile results from an erosion process (Aka, 1991). The action of erosion being intense in these zones, it accentuates the unevenness. Lithology is an explanatory factor of this type of relief because the more competent a rock is, the less it tends to erode. While less rock is competent, the more it tends to erode. It is therefore necessary to add the force of the current of water.
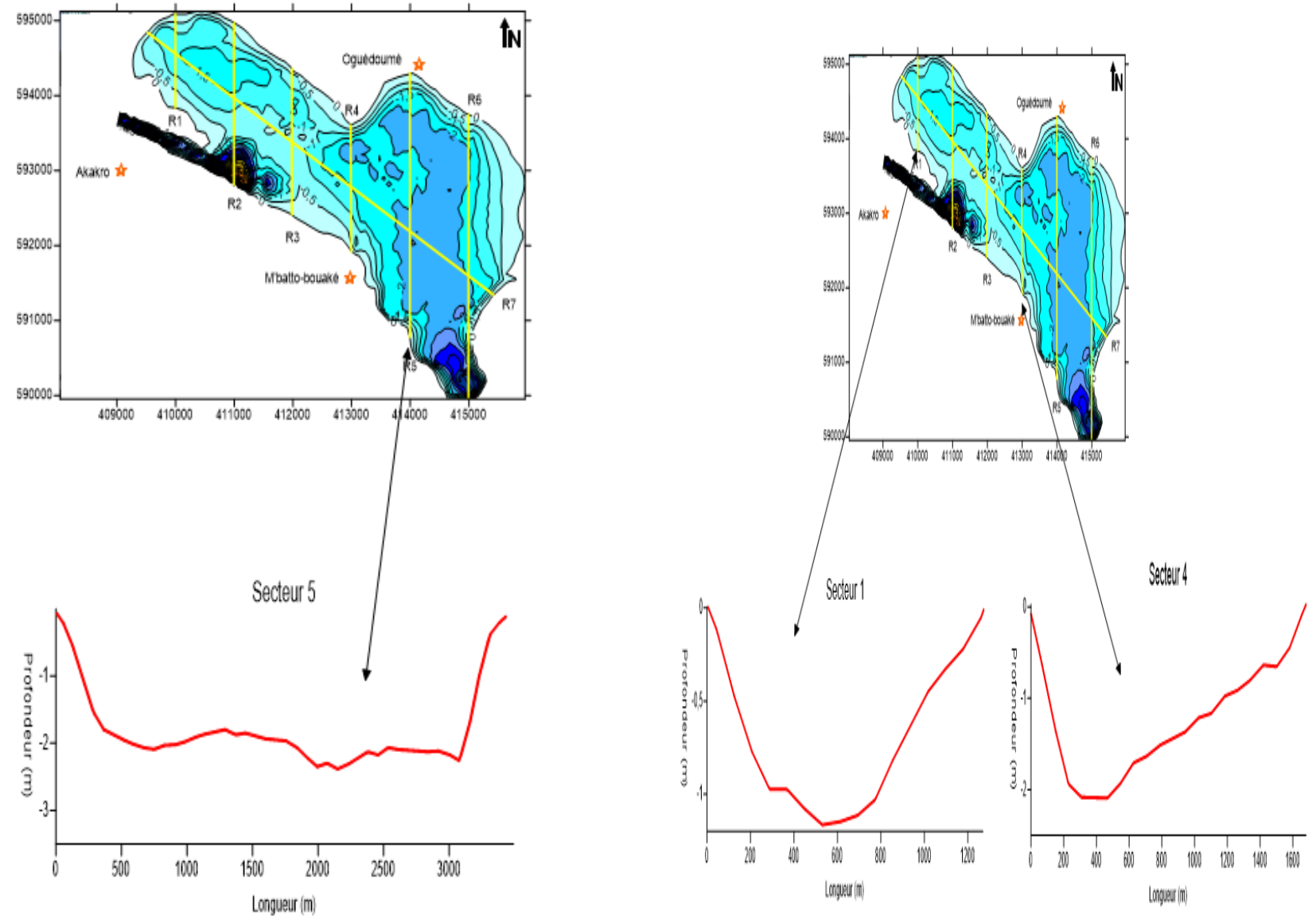

Figure 8: Bathymetric "U" shaped profile of the Potou Lagoon (2018)

\section{CONCLUSION}

Analysis of the recent bathymetric map shows that the Potou Lagoon is shallow, with an average depth of 2.11 $\mathrm{m}$. The maximum depth is $13 \mathrm{~m}$. We also note the preponderance of high ground on the numerical model, which reflects a rather calm sedimentation on the whole of the lagoon. The analysis of the profiles shows channels of " $U$ ", "V" and intermediate morphology. Thus, the "U" channels, translate a balance between the agents of accumulation and erosion, the channel in "V" translates an erosion and the channel in intermediate is between channels in $U$ and in $\mathrm{V}$.

\section{SOURCES OF FUNDING}

This research received no specific grant from any funding agency in the public, commercial, or not-for-profit sectors. 


\section{CONFLICT OF INTEREST}

The author have declared that no competing interests exist.

\section{ACKNOWLEDGMENT}

None.

\section{REFERENCES}

[1] Adopo K. L. (2009). Caractérisation du fonctionnement hydro-sédimentaire d'un environnement estuarien en zone tropicale: cas de l'embouchure du fleuve Comoé à Grand- Bassam(sud-estdelaCôted'Ivoire). Thèse de Doctorat, Université de Cocody, 179p.

[2] Amani M. (2012). Essais de modélisation hydrodynamique de la circulation des masses d'eau et de la dispersion saline dans un environnement côtier peu profond de la lagune Digboué (San-Pédro, Côte d’Ivoire). Thèse unique, Université Félix HouphouetBoigny de Cocody, 170 p.

[3] Aka K. (1991). La sédimentation quaternaire sur la marge de Côte d'Ivoire: Essai de modélisation. Thèse Doctorat Etat, ès Sc. Nat., Université Côte d'Ivoire. ${ }^{\circ} 146,233 p$.

[4] Monde S. (1997). Nouvelles approches de la cartographie du plateau continental de Côte d'Ivoire: Aspects morphologiques et sédimentologiques. Thèse de Doctorat de 3ème Cycle. Université de Cocody- Abidjan, 325 p.

[5] Reiner S., GeschäftsbereichV. et Carl Z. (1992). Photogrammetric systems, Zeiss Infor., Oberkochen (Germany), vol. 31, n 103, pp. 57-59.

[6] Tastet. J. P et Guiral D. (1994). Géologie et sédimentologie in: environnement et ressources aquatiques de la Côte d'Ivoire. T.2. Les milieux lagunaires. Orstom pp35-58. 